\title{
A Review of the Factors Influencing Enterprise Risk Taking
}

\author{
Liping Chen \\ School of Accounting \\ Zhongnan University of Economics and Law \\ Wuhan, China 430073
}

\author{
Jingjing Xu \\ College of Business \\ Tianshui Normal University \\ Tianshui, China 741000
}

\begin{abstract}
Enterprise risk taking is a decision-making behavior orientation and an intermediate process of realizing innovation-driven development strategy. In this paper, Francis and Holloway's literature review method was used for reference. By sorting out relevant literature, the internal and external factors influencing enterprise risk taking are systematically summarized, and the future research direction was pointed out on this basis.
\end{abstract}

Keywords-enterprise risk taking; decision-making behavior; internal factors; external factors

\section{INTRODUCTION}

Enterprise risk taking reflects a behavioral orientation of managers in the process of investment decision-making which can be manifested particularly in the analysis and option conducted in the investment project that that can bring expected income and cash flow and are full of uncertainties. If there is strong willingness to take risks, the investment projects that are risky but can increase the value of the enterprise will not be abandoned, which fully reflects the subjective willingness of decision makers. Therefore, the high level of enterprise risk taking reflects the adventurous and innovative spirit of decision makers. It is the cornerstone to improve the competitive advantage of enterprises, contribute to the survival and development of enterprises, and also the source power of a country's long-term economic growth.

Since the 18th national congress of the CPC made the deployment of innovation-driven development strategy, the state council issued the "opinions of the CPC central committee and the state council on deepening institutional reform and accelerating the implementation of innovationdriven development strategy" in March 2015, and released the outline of the national strategy for innovation-driven development in May 2016, and in 2017, the party's 19th national congress put innovation as the top five development concepts. These arrangements and the issuance of documents are consistent in placing innovation at an unprecedented height in order to enhance China's economic competitiveness. Whether it is innovation based on the country's high-end scientific and technological achievements, innovation aimed at a large number of invention patent achievements or innovation in the process of internationalization, it will face high risk challenges in the whole innovation process. Taking enterprises and organizations as examples, all innovation activities are characterized by high risks, high returns, long payback period of investment, high short-term costs and low probability of success, which means that innovation projects are often high-risk but high-value investment projects. The state is encouraging enterprises and organizations to strive to avoid risk aversion and actively increase the level of risk taking while encourage innovation. This is to make innovation become the common value pursuit and behavior habit of the whole society and thus to improve the competitiveness of China's economy. Therefore, the realization of innovation must appropriately improve the level of risk taking.

In recent years, scholars have paid great attention to enterprise risk taking and produced a large number of literatures on risk taking, which provides abundant materials for the writing of this paper. The literature review method of this paper mainly draws on the views of Francis and Holloway (2010). They believe that comprehensive reporting is only a good wish, and is neither desirable nor realistic in practice, considering the number, scale, diversity and increasing new content of the literature. Therefore, this paper combines relevant studies, detailed descriptive articles and other review articles to illustrate the evolution and research contribution of relevant literature on enterprise risk taking. On the basis of summarizing the previous research results, this paper makes a special systematic summary on the influencing factors of enterprise risk taking. It sorts out the internal factors and external factors, and looks forward to the future research direction, so as to stand on the shoulders of giants to see farther, and provide some reference for scholars who do this research.

\section{INFLUENCING FACTORS OF ENTERPRISE RISK TAKING}

As a philosophical principle puts it, everything will be affected by both internal and external factors, so it is also true of enterprise risk taking. There are abundant literatures on the influencing factors of enterprise risk taking. This paper mainly sorts out the internal factors - enterprise level factors and external factors - external environmental factors.

\section{A. Internal Factors of the Enterprise}

Researches on risk taking from the perspective of the ownership nature, performance growth, industry category 
and enterprise type of an enterprise are mostly concentrated in the early literature. Later literature is mostly based on the agency problem caused by the separation of ownership and management right. It focuses on how to reduce the underexposure of managers to risk caused by the agency problem and made a lot of analysis respectively from the perspectives of corporate governance and management characteristics. This paper summarizes the influencing factors at the enterprise level mainly from the three aspects of enterprise basic characteristics, corporate governance and management characteristics.

1) Basic characteristics of the enterprises: Unlike other enterprises, family enterprises have a strong motivation to transfer wealth to the next generation, so they tend to avoid risks (Anderson et al., 2003; Su and Lee, 2013). However, there are also different conclusions. Nguyen (2011) took Japanese enterprises as samples and found that family enterprises have a strong motivation to increase enterprise value, which in turn promotes enterprise risk taking. Lee (2018) took Korean enterprises as samples and found that there was a non-linear u-shaped relationship between family ownership and enterprise risk taking. When family ownership accounted for a small proportion of enterprise risk taking, it tends to take less risk, while when the relative proportion increased, it would promote enterprises to increase investment in risky projects. Boubakri (2013) found that compared with private enterprises, state-owned enterprises are vulnerable to government intervention and behavioral decisions are mostly based on political factors, so they will choose more stable and low-risk investment projects, and further found that the risk level of state-owned enterprises significantly increased after privatization (Boubakri et al. , 2013; Yu minggui et al., 2013). Habib and Hasan (2015) found that enterprises at different stages of their life cycle showed different levels of risk taking. Periods of development and decline are associated with higher risk taking. The reason is that during the development period, enterprises increase investment to prevent competitors from entering and ensure favorable position; while the enterprise of recessionary period adopts risky investment project to try hard, hope to redeem adverse situation. When the enterprise is in the growth and maturity stage, the operation is relatively stable, without excessive investment expenditure, and takes relatively low risk.

2) Corporate governance: Scholars have mainly discussed the influence of ownership structure, board characteristics and management incentive on enterprise risk taking.

The ownership structure of an enterprise has a significant constraint on the behavior of the management. Attig et al. (2013) pointed out that major shareholders have the motivation to supervise the management and can reduce the low level of risk taking caused by the opportunistic behavior of the management. Koerniadi et al. (2014) found that the existence of equity balance improves the supervision level of New Zealand enterprises and promotes their choice of high- risk and high-return projects. With the increase of ownership, major shareholders have a strong incentive to increase enterprise returns by increasing risk projects, as some scholars have also found that ownership concentration is positively correlated with enterprise risk taking (Nguyen, 2011). But on the other hand, major shareholders also have a strong incentive to pursue private returns and may adopt more robust investment projects to ensure these returns (Jone, 2008). Faccio et al. (2011) further studied and found that only when major shareholders have diversified investment, the positive relationship between ownership of major shareholders and enterprise risk taking was established, and the level of enterprise risk taking controlled by major shareholders with diversified investment was relatively higher. Mishra (2011) found that major shareholders have the ability and motivation to adopt prudent investment policies to obtain private profits. The emergence of dominant shareholders reduces the risk of enterprises, while the emergence of multiple major shareholders can improve the risk of enterprises.

There are also studies focused on the impact of foreign investors on corporate risk taking. Vo, Xuan Vinh (2016) took Vietnamese enterprises as samples and found that foreign investors in the stock market of Vietnam are concerned about the long-term perspective rather than shortterm earnings, so foreign investors restrain the risk taking activities of enterprises.

Wright et al. (1996) found that institutional investors have the motivation to enhance enterprise value by promoting enterprise risk activities. However, Zhu Yujie and Ni Xiaoran (2014) took listed companies in China as an example and found that shareholding by institutional investors significantly reduced the risk level of enterprises. When they further distinguish the types of institutional investors, they found the shareholding of non-independent institutional investors has more significant and sustained effect on limiting the risk taking of the enterprise.

The board of directors will also have an important impact on corporate risk taking. Wang (2012) found that smaller boards of directors are more likely to encourage CEOs to take risks and make more risky investments. Nakano (2012) believes that the larger the board size is, the more difficult it is to reach a compromise, and a larger the decision-making group tends to adopt non-extreme decisions. This means that larger boards reduce corporate risk-taking, but growth opportunities mitigate the relationship between board size and risk-taking. Ferrero (2012) comprehensively studied the influence of the board of directors on enterprise risk taking and found that the size of the board of directors was significantly negatively correlated with enterprise risk taking, while the concurrent positions of independent director, chairman and general manager had no significant impact on enterprise risk taking. However, Beasley (1996) came to a different conclusion that the increase in the proportion of independent directors improves the independence of the board of directors and makes its supervisory role more effective, thus promoting enterprise risk taking. Later, based on all listed British financial sectors, scholar Akbar et al. (2017) examined how the size of the board of directors, the 
independence of the board of directors and the role of CEO and chairman in the board of directors affected the corporate risk taking of financial companies. It was found that the presence of non-executive directors and powerful CEOs on corporate boards reduced the level of corporate risk taking of financial companies. Some scholars have also discussed the influence of the heterogeneity of board members on enterprise risk taking. Harjoto (2014) believes that the gender, age, race, tenure and other differences of board members represent different abilities and cognitive levels of individuals. And the diversity helps board members analyze problems from multiple backgrounds and perspectives, and is more conservative and prudent in the choice of investment projects.

In order to solve the agency problem caused by the separation of ownership and control, management incentive is used to solve the problem of inconsistency between the objective function of investors and management. Therefore, the design of incentive mechanism will directly affect the decision-making behavior of management. The common incentive mechanism mainly includes salary incentive and stock option, which can urge the management to overcome the risk aversion tendency and increase the risk level of the enterprise. Shivaram et al. (2002) found that stock options can prompt managers to expand investment in projects with high risks but relatively high returns, thus promoting enterprise risk taking. Wright et al. (2007) systematically studied the influence of executive incentive on enterprise risk taking, and found that the higher is the proportion of fixed part of executive compensation and the lower is the risk taking of enterprises. However, the granting of stock options to managers can enhance enterprise risk taking. There is a curvilinear relationship between the shareholding ratio of senior executives and corporate risk taking. Zhang Ruijun (2013) empirically tested that monetary compensation can effectively improve the level of enterprise risk taking. Kini and Williams (2012) also hold the view that the incentive of internal championship can encourage the management to pursue high-risk and high-return projects, improve performance and obtain promotion opportunities. While DeFusco et al. (1991) found that when the equity incentive of senior executives increased, the company's decisionmaking became more conservative.

3) Managerial characteristics: Hambrick and Mason (1984) as the representatives put forward the theory of highlevel echelon and believed that managers are heterogeneous and limited rational people. Such heterogeneity and limited rationality will have an important impact on the decisionmaking behavior of companies. Since this theory was put forward, a large number of scholars have discussed the impact of different characteristics of managers on enterprise risk taking based on this theory. Some scholars believe that gender, age, experience and other differences will lead to different risk orientation of individuals, and the risk orientation of managers is positively correlated with the risk level of enterprises (Palmer and Wiseman, 1999). Haider et al. (2018) took Chinese listed companies as samples and found that whether state-owned or non-state-owned, the greater the CEO's power is, the lower the risk an enterprise takes.

Women are more cautious and conservative in their decision-making than men. Faccio (2014) directly compared the differences in risk taking between female CEOs and male CEOs, and found that enterprises led by female CEOs showed a lower level of risk taking. In his further analysis, it is also found that the low risk of female CEOs leads to insufficient investment and inefficient capital allocation in enterprises. He weifeng, a Chinese scholar, also holds the same view (2016). Peltomaki (2015) studied from the perspective of age and found that the older the CEO and $\mathrm{CFO}$ are, the more conservative they are, which will restrict the enterprise to choose projects with higher risks. In addition, CEO's personal experience will also have different influences on enterprise risk taking. Carpenter (2003) showed that for high-tech companies in emerging countries, companies controlled by investors and managers with international experience show a more reasonable level of risk taking. Malmendier (2011) examined the impact of CEO's war experience and "great depression" experience on corporate financial decisions. He studied American companies and found that CEOs who had been through the war were more aggressive in their financial decisions and those who had been through the great depression were more cautious, with significant differences in risk appetite. Overconfident managers show strong risk preference and will choose more investment projects with high risk and high return (Gervais, 2003). Li and Tang, 2010), Baker and Wurgler (2011), yu minggui et al. (2013a) also supported the above views. Ferris (2017) verified for the first time that CEO's social relationship would affect the company's decision-making behavior. He found that CEOs with high levels of social capital exhibit a higher level of risk-seeking behavior that leads to greater volatility in stock returns and earnings.

\section{B. External Environmental Factors}

This paper summarizes the influencing factors of external environment from three aspects: macroeconomic environment, external institutional environment and cultural environment.

1) Macroeconomic environment: From the perspective of macro-economic environment, most of the literatures on enterprise risk taking focus on the impact of macroeconomic form or a specific policy. For example, Arif and Lee (2014), Mclean and Zhao (2014) believe that the level of economic growth of a country will affect the risk-taking tendency of enterprises. When a country is in a period of prosperity and development, it is accompanied by a high growth expectation and easy financing environment, and the overall investment of enterprises is at a high level; when the economy is in recession, the market is in downturn and financing constraints become severe, investment decisions become more conservative, and the level of risk taking is lower. Bargeron (2010) conducted an empirical study on the role of sarbanes-oxley act (SOX) on enterprise risk taking, and found that r\&d investment, stock return volatility of 
enterprises affected by SOX decreased significantly while and cash and cash equivalents increased markedly. Wang Yonghai (2013) examined the specific impact of China's enterprise income tax reform on enterprise risk taking in 2007. The study found that companies with lower tax rates significantly reduced their risk levels and those with higher tax rates significantly increased their risk levels. In addition, He Weifeng (2017) investigated the specific impact of EVA performance evaluation comprehensively implemented by China's central enterprises on enterprise risk taking in 2010, and found that after the change of performance evaluation system, risk taking behavior of central enterprises became more active.

2) External institutional environment: The legal system and financial clauses in the region where the enterprise is located will affect the ownership structure, investment strategy, incentive policies and governance mechanism of the enterprise. For example, better investor protection can promote enterprises to increase investment in projects that bring higher risk but can increase enterprise value. The better the protection of investors' rights, the easier it is for investors to accept "high risk and high return" type of investment projects, so as to improve the level of enterprise risk taking (Paligorova, 2010). Bargeron, 2010). While better creditor protection will lead to higher bankruptcy costs and lower enterprise risk (Chava, 2008; Nini, 2009; Acharya, 2011).

3) Cultural environment: Many scholars have shown that, even in the context of globalization in which a large number of professional managers exist, aspects in informal institutional level (such as culture) has an important impact on the decision-making of companies (Leuz, 2006; Griffin, 2014). Li (2013) examined the influence of a country's culture on enterprise risk taking. found that the culture of individualism has a significant positive impact on enterprise risk taking, while the cultural value of avoiding uncertainty has a significant negative impact on enterprise risk taking. And the above relationship is affected by the autonomy of management.

\section{CONCLUSION}

Risk taking is an important part of enterprise strategic decision-making. As people become more and more aware of risk taking, they realize risks are not equal to loss and there are even opportunities contained in risks. Therefore, appropriately raising the level of risk taking will be crucial for enterprises to gain competitive advantages, enhance the value of enterprises, and thus to improve the innovation ability of the whole country, and achieve economic growth.

Although the research on enterprise risk taking started relatively late, it has attracted the attention of scholars in economics, finance, management and other disciplines and obtained some valuable research conclusions. Among them, it has been effectively verified that risk taking contributes to the improvement of enterprise value, innovation input and competitiveness. However, from the perspective of research content, breakthroughs should be made in the following aspects in the future:

\section{A. Discussing the Impact of Cultural Environment on Enterprise Risk Taking}

The level of enterprise risk taking will ultimately fall on the managers in the decision-making team. The difference of managers' decision-making mainly comes from their individual characteristics, traditional culture and institutional background. At present, there are abundant researches based on individual characteristics of managers, such as gender, age, education background, work experience, belief, preference, etc., but there is still insufficient discussion done from the cultural perspective of managers. The cultural environment managers live in has a profound impact on their behaviors and is often unlikely to change in a short time; There are cross-cultural differences in the perception, inheritance and evaluation of risks in different countries and regions (Liao Zhongju) Cultural differences shape managers' different attitudes towards risks, which in turn influence their choice of corporate decision-making behaviors. At present, there is a lack of research on enterprise risk taking from the perspective of cultural factors. In addition to the external environmental factors, the internal rules and regulations of the enterprise will also affect the behavior tendency of decision makers. For example, fault-tolerant corporate cultural environment, policies that encourage innovation and assessment mechanisms that focus on long-term effects rather than short-term effects will all present a high level of risk taking. In the future, studies on the impact of cultural environment on corporate risk taking can be enriched.

\section{B. Exploring the Countermeasures to Improve the Level of Enterprise Risk Based on China's Special National Conditions}

China's political system is different from that of some countries in Europe and the United States in that enterprises are subject to a greater degree of government intervention and different ownership properties have different risk bearing mechanisms. Scholars have discussed a lot about this aspect, but how to solve the existing practical problems in view of such differences is insufficient. The overall risk level of Chinese enterprises is far lower than that of the United States, Canada, Britain and other countries (Jone et al., 2008). In the face of the current situation of insufficient risk bearing, innovation and competitiveness of Chinese enterprises, it is more meaningful to provide solutions and measures in view of the background of China's political system, to solve practical problems for theoretical researches are supposed to serve practice ultimately.

\section{Enriching the Research on the Subject of Enterprise Risk Bearing}

Domestic articles take a one-sided focus on the subject of the listed non-financial companies when studying enterprise risk taking while researches on the subject of unlisted financial companies are rare. As of September 2017, there are over 28.5 million domestic enterprises in China, of which there are only over 3,300 listed ones, accounting for about 
$0.01 \%{ }^{1}$. It needs further examining whether the researches that only use the sample of listed companies except for financial companies can reflect the real condition of China's enterprise risk taking or not. What's more, researches focused on financial companies are in severe shortage and are mainly about risk management, with a scarce relevance to risk taking. And there remain huge differences of the level of risk taking among different sectors. Therefore future studies can conduct more detailed investigation on different risk taking subjects and make them more representative.

\section{REFERENCES}

[1] Akbar S, Kharabsheh B, Poletti-Hughes J, et al. Board structure and corporate risk taking in the UK financial sector [J]. International Review of Financial Analysis, 2017, 50:101-110.

[2] Anderson R C, Mansi S A, Reeb D M. Founding family ownership and the agency cost of debt [J]. Journal of Financial Economics, 2002, 68(2):263-285.

[3] Arif S, Lee C M C. Aggregate Investment and Investor Sentiment[J]. Social Science Electronic Publishing, 2014, 27(11):3241-3279.

[4] Attig N, Ghoul S E, Guedhami O, et al. The governance role of multiple large shareholders: evidence from the valuation of cash holdings[J]. Journal of Management \& Governance, 2013, 17(2):419451

[5] Baker M P, Wurgler J. Behavioral Corporate Finance: An Updated Survey[J]. Social Science Electronic Publishing, 2011, 2:357-424.

[6] Beasley, M.S. An empirical analysis of the relation between the board of director composition and financial statement fraud[J]. The Accounting Review, 1996,71(4):443-665.

[7] Boubakri N, Cosset J C, Saffar W. The role of state and foreign owners in corporate risk-taking: Evidence from privatization [J]. Journal of Financial Economics, 2013, 108(3):641-658.

[8] Carpenter M A, Pollock T G, Leary M M. Testing a model of reasoned risk - taking: governance, the experience of principals and agents, and global strategy in high - technology IPO firms[J]. Strategic Management Journal, 2003, 24(9):803-820.

[9] Chava S, Roberts M R. How Does Financing Impact Investment? The Role of Debt Covenants[J]. Journal of Finance, 2008, 63(5):20852121.

[10] Defusco R A, Zorn T S, Johnson R R. The Association between Executive Stock Option Plan Changes and Managerial Decision Making[J]. Financial Management, 1991, 20(1):36-43.

[11] Faccio, Mara, Marchica, MariaTeresa, Mura, Roberto. CEO Gender and Corporate Risk-Taking[J]. Social Science Electronic Publishing, 2014, 39:193-209.

[12] Faccio, Mara, Marchica, MariaTeresa, Mura, Roberto. CEO Gender and Corporate Risk-Taking[J]. Social Science Electronic Publishing, 2014, 39:193-209.

[13] Ferrero-Ferrero I. The impact of the board of directors characteristics on corporate performance and risk-taking before and during the global financial crisis[J]. Review of Managerial Science, 2012, 6(3):207-226.

[14] Ferris S P, Javakhadze D, Rajkovic T. CEO Social Capital, RiskTaking and Corporate Policies[J]. Journal of Corporate Finance, 2017, 47:46-71.

[15] Francis G, Holloway J. What have we learned? Themes from the literature on best - practice benchmarking[J]. International Journal of Management Reviews, 2010, 9(3):171-189.

[16] Gervais S, et al. Overconfidence, Investment Policy, and Executive Stock Options[R].Social Science Electronic Publishing, 2003.

The data are from the website of the State Administration for Market Regulation and "The Analysis of National Enterprise Development Since the 18th CPC National Congress".(in Chinese)
[17] Habib A and Hasan M M. Firm life cycle, corporate risk taking and investor sentiment [J]. Accounting \& Finance, 2015, doi:10.1111/acfi.12141

[18] Haider J, Fang, HX. CEO power, corporate risk taking and role of large shareholders[J]. Journal Of Financial Economic Policy, 2018,10(1):55-72.

[19] Harjoto M A, Laksmana I, Yang Y W. Board Diversity and Corporate Risk Taking[J]. Social Science Electronic Publishing, 2014.

[20] Jiatao Li, Tang Y. CEO Hubris And Firm Risk Taking In China: The Moderating Role Of Managerial Discretion[J]. Academy of Management Journal, 2010, 53(1):45-68.

[21] Kini $\mathrm{O}$ and Williams R. Tournament incentives, firm risk, and corporate policies[J]. Journal of Financial Economics, 2012,103(2):350-376

[22] Koerniadi H, Krishnamurti C, Touranirad A. Corporate Governance and Risk-Taking in New Zealand[J]. Australian Journal of Management, 2014, 39(2):227-245.

[23] Leonce L. Bargeron, Kenneth M. Lehn, Chad J. Zutter. SarbanesOxley and corporate risk-taking [J]. Journal of Accounting \& Economics, 2010, 49(1):34-52.

[24] Mclean R D, Zhao M X. The Business Cycle, Investor Sentiment, and Costly External Finance[J]. Social Science Electronic Publishing, 2014, 69(3):1377-1409.

[25] Mishra D R. Multiple Large Shareholders and Corporate Risk Taking. Evidence from East Asia[J]. Corporate Governance An International Review, 2011, 19(6):507-528

[26] Nakano M, Nguyen P. Board Size and Corporate Risk Taking: Further Evidence from Japan[J]. Corporate Governance An International Review, 2012, 20(4):369-387.

[27] Nini G, Smith D C, Sufi A. Creditor control rights and firm investment policy [J]. Social Science Electronic Publishing, 2006, 92(3):400-420.

[28] Paligorova T. Corporate Risk-Taking and Ownership Structure[R] Staff Working Papers, 2010.

[29] Palmer T B, Wiseman R M. Decoupling risk taking from income stream uncertainty: a holistic model of risk[J]. Strategic Management Journal, 1999, 20(11):1037-1062.

[30] Peltomäki J, Swidler S, Vähämaa S. Age, Gender, and Risk-Taking: Evidence from the S\&P Executives and Firm Riskiness[R]. Social Science Electronic Publishing, 2015

[31] Shivaram Rajgopal, Terry Shevlin. Empirical evidence on the relation

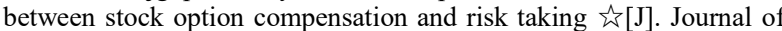
Accounting and Economics, 2002, 33(2):145-171.

[32] $\mathrm{Su} \mathrm{W}$ and Lee $\mathrm{C} \mathrm{Y}$. Effects of corporate governance on risk taking in Taiwanese family firms during institutional reform [J]. Asia Pacific Journal of Management, 2013, 30(3):809-828

[33] Ulrike Malmendier, Geoffrey Tate, Jon Yan. Overconfidence and Early-Life Experiences: The Effect of Managerial Traits on Corporate Financial Policies[J]. The Journal of Finance, 2011, 66(5):1687-1733.

[34] Viral V. Acharya, Yakov Amihud, Lubomir Litov. Creditor rights and corporate risk-taking $\hat{\tau}[\mathrm{J}]$. Journal of Financial Economics, 2011, 102(1):150-166.

[35] Wang C J. Board size and firm risk-taking[J]. Review of Quantitative Finance \& Accounting, 2012, 38(4):519-542.

[36] Wright P, Kroll M, Krug J A, et al. Influences of top management team incentives on firm risk taking[J]. Strategic Management Journal, 2007, 28(1):81-89.

[37] Xuan V V. Foreign investors and corporate risk taking behavior in an emerging market[J]. Finance Research Letters, 2016, 18:273-277.

[38] He Weifeng, Liu Wei. EVA performance evaluation and enterprise risk taking [J]. China Soft Science, 2017(6):99-116. (in Chinese)

[39] Liao Zhongju. Review and prospect of research on organizational risk tendency $[\mathrm{J}]$. Foreign Economies and Management, 2015, 37(8):7886. (in Chinese)

[40] Wang Jinghua, Mao Ning. Review and prospect of enterprise risk bearing research $[\mathrm{J}]$. Foreign Economies and Management, 2015(12):44-58. (in Chinese) 
[41] Yu Minggui, Li Wengui, Pan Hongbo. Privatization, property right protection and enterprise risk taking [J]. Economic Research Journal, 2013(9):112-124. (in Chinese) 